\title{
ЭТИЛЕН-ДИАМИДО-ДИИЗОПРОПИЛЕН-О,О'-ДИНАТРИЙ- СРЕДСТВО ДЛЯ ПОВЫШЕНИЯ КАЧЕСТВА ТЕХНИЧЕСКОЙ ВОДЫ, ИСПОЛЬЗУЕМОЙ В СИСТЕМАХ ГОРОДСКОГО ТЕПЛОСНАБЖЕНИЯ
}

\author{
В. В. Овчинников, П. А. Гуревич
}

\begin{abstract}
ВИТАЛИЙ ВИТАЛЬЕВИЧ ОВЧИННИКОВ - д.х.н., профессор кафедры общей химии и экологии Казанского национального исследовательского технического университета им. A.H. Туполева. E-mail: chem_vvo@mail.ru.
\end{abstract}

ПЕТР АРОНОВИЧ ГУРЕВИЧ - д.х.н., профессор кафедры органической химии Казанского национального исследовательского технического университета им. A.H. Tyполева.E-mail: petr_gurevich@mail.ru.

Казанский национальный исследовательский технический университет им. А.Н. Туполева - КАИ, ул. К. Маркса, 10, Казань, Российская Федераџия, 420111.

Проведен анализ воды, которая используется в городских нагревательных системах, и установлено, что проводится неполная очистка от солей различных металлов, как это требуется по методическим рекомендациям по расчету количества и качества принимаемых сточных вод и загрязняющих веществ системы канализации. Для сохранения бойлерной аппаратуры часто используется нитрилотрифосфонат циннка (NTPZn) потому что он был найден как эффективное средство для очистки воды от солей металлов. Также было установлено, что такому веществу необходимо иметь две или три группь $P=O$ u $-N=R_{2}$. Есть большая проблема с используемым антинакипином третьего класса опасности, поскольку при вьсокой температуре, которая имеет место бойлерах, структура этого соединения может разрушаться с выделением таких токсических веществ как цуианиды.

Этилен-диамидо-диизопропилен-О,О'-динатрий-дифосфонат (EDDDP), имеющий 4-ый класс опасности согласно биохимическим исследованиям, был впервые синтезирован с хорошим выходом для изелей увеличения качества технической дренажной воды. Синтез был проведен через реакцию конденсации между 1-метилакриловой кислотой и 1,2-этилендиамином с последующей реакцией Пудовика полученного промежуточного соединения с динатрийфосфористой кислотой.

Был сделан анализ технической дренажной воды и получены данныле жесткости, общей щелочности, токсикологических свойств и эффективности воды в отсутствие и в присутствии EDDDP.

Токсикологический контроль был проведен в соответствии с «Критериями отнесения отходов к классам опасности для окружающей природной среды», Министерства природньх ресурсов Российской Федераџии от 2001 года и дал заключение, что EDDDP не токсичен по сравнению с бактерией Daphniamagna, которая была взята за стандарт.

Ключевые слова: техническая вода, жесткость воды, щелочность, фосфорное соединение, анти-накипин, эффективность, классопасности. 


\title{
ETHYLENE-DIAMIDO-DIISOPROPYLEN- O,O'-DINATRIUM-DIPHOSPHONATE IS A MEANS FOR THE RISE OF QUALITY OF TECHNICAL WATER, USEDIN THE SYSTEMS OF A CITY WARM WATER SUPPLY
}

\author{
V.V. Ovchinnikov, P.A. Gurevich \\ Kazan National Research Technical University named after A.N. Tupolev-KAI, K. Marx st., 10, Kazan, 420111, \\ Russia.
}

The analysis of water used in urban heating systems has been carried out, and it has been found that incomplete purification of salts of various metals is carried out, as required by the methodological recommendations for the calculation of the amount and quality of waste water received and pollutants of the sewerage system. Zinc nitrilotrifosphonate (NTPZn) is often used to preserve boiler equipment because it has been found to be an effective means for purifying water from metal salts. It has also been found that such a substance needs to have two or three groups $P=O$ and $-N=R_{2}$. There is a big problem with the third class of danger antinacipine used, since at the high temperature that boilers occur, the structure of this compound can break down with the release of toxic substances such as cyanides.

Ethylene diamido-diisopropylene-O,O'-dinatrium diphosphonate (EDDDP), having a $4^{\text {th }}$ hazard class according to biochemical studies, was first synthesized with good yield for the purpose of increasing the quality of technical drainage water. The synthesis was carried out through a condensation reaction between 1-methylacrylic acid and 1,2-ethylenediamine, followed by Pudovik's reaction of the resulting intermediate with disodium phosphorous acid.

Technical drainage water was analyzed and data were obtained on stiffness, general alkalinity, toxicological properties and water efficiency in the absence and presence of EDDDP. Toxicological control was carried out in accordance with the Criteria for Classification of Waste as a Hazard to the Natural Environment, Ministry of Natural Resources of the Russian Federation of 2001year and concluded, that EDDDP was not toxic compared to the bacterium Daphnia magna, which was taken as a standard.

Keywords: technical water, rigidity of water, alkali properties, phosphoric compound, anti-scum, effectivity, class of danger.

\section{Introduction}

The organic complex-formation substances are used for the waterpurify after different technological processes [15]. The akin organic compounds as amino acids or substances with phosphor-containing fragments in their structures also often can be used for the extraction of metal ions in liquids to reduce a rigidity of water and doher more potable [6].

So,nitriletriphosphonate of zinc (NTPZn) was often used as a means against the scum in the systems of a city warm supply [7, 8]. The analysis of such literary data showed, that the substances with the metalextracting (for example $\mathrm{Ca}, \mathrm{Mg}$ or $\mathrm{Fe}$ ) properties must have in the composition from one to three phosphoric groups $(=\mathrm{P}(\mathrm{O}) \mathrm{O})$ and nitrogen $(\mathrm{NHR})$ containing fragments [911].

\section{Methods and experiments}

Taking into account profitable, cheap and ecological conditions, we undertook the synthesis of the required extract compound for the aims of the warmenergetic systems of the town economy management. The synthesis of ethylene-diamido-diisopropylen$\mathrm{O}, \mathrm{O}^{\prime}$-dinatrium-diphosphonate (EDDDP) was conducted in some stages. On the first of them the condensation process was carried out between 1-methylacrylic acid $(1,28.7 \mathrm{~g}, 0.67 \mathrm{~mol})$ and 1,2-ethylenediamine (2, $20.02 \mathrm{~g}, 0.33 \mathrm{~mol}$ ) with formation of dimethyl-diacryl- 
ethylene-diamide (3, $60.2 \mathrm{~g}$, yield is $92.3 \%$ ) at the room temperature in benzene with a trap for the water isolation from the reaction mixture (equation 1).

$$
\begin{aligned}
& 2 \mathrm{CH}_{2}=\underset{1}{\mathrm{C}\left(\mathrm{CH}_{3}\right) \mathrm{CO}_{2} \mathrm{H}}+\underset{2}{\left(\mathrm{CH}_{2}\right)_{2}}\left(\mathrm{NH}_{2}\right)_{2} \rightarrow \\
& \rightarrow\left[\mathrm{CH}_{2}=\mathrm{C}\left(\mathrm{CH}_{3}\right) \mathrm{C}(\mathrm{O}) \mathrm{NHCH}_{2}\right]_{2}+2 \mathrm{H}_{2} \mathrm{O} \\
& 3
\end{aligned}
$$

The next stage consisted in the preparation of $30 \%$ (to volume) base-alcohol-water mixture with industrial phosphoric acid; during of this process the two hydroxyl groups of phosphoric acid were exchanged on $\mathrm{NaO}$ groups of sodium hydroxide and the required substance for next synthesis was $\mathrm{Na}_{2} \mathrm{HPO}_{3}$.

The last stage of synthesis of required extract means consisted in the use of famous Pudovik-reaction [12]: in the addition reaction of previously received reagent $(\mathrm{NaO})_{2} \mathrm{P}(\mathrm{O}) \mathrm{H}(63.2 \mathrm{~g}, 0.62 \mathrm{~mol})$ to double bonds of compound $(3,60.2 \mathrm{~g}, 0.31 \mathrm{~mol})$ at $343348 \mathrm{~K}$ during of two hours. After evaporation of the rests of benzene and alcohol the required compound (4) represented yourselves $105.4 \mathrm{~g}$ with the yield $91.8 \%$ (equation 2)

$$
\begin{gathered}
{\left[\mathrm{CH}_{2}=\mathrm{C}\left(\mathrm{CH}_{3}\right) \mathrm{C}(\mathrm{O}) \mathrm{NHCH}_{2}\right]_{2}+2(\mathrm{NaO})_{2} \mathrm{P}(\mathrm{O}) \mathrm{H} \rightarrow} \\
\mathbf{3} \\
\rightarrow\left[(\mathrm{NaO})_{2} \mathrm{P}(\mathrm{O}) \mathrm{CH}_{2} \mathrm{CH}\left(\mathrm{CH}_{3}\right) \mathrm{C}(\mathrm{O}) \mathrm{NHCH}_{2}\right]_{2} \\
4
\end{gathered}
$$

For extract means $\left(4, \mathrm{C}_{10} \mathrm{H}_{18} \mathrm{~N}_{2} \mathrm{O}_{8} \mathrm{P}_{2} \mathrm{Na}_{2}\right)$ was found C $30.94 \%$, H $3.86 \%$; calculated C $29.88 \%$, H $4.48 \%$. The signal at $4.6 \mathrm{ppm}$ has been found in $\mathrm{NMR}{ }^{31} \mathrm{P}$ spectra, which corresponds to organophosphorus structures with $\mathrm{P}(\mathrm{O}) \mathrm{CH}_{2}$ groups. There are bands (v) in IR spectrum at $10301100(\mathrm{P}-\mathrm{O}-\mathrm{C}), 1285(\mathrm{P}=\mathrm{O}), 28902980$ (C$\mathrm{H}), 27502800(\mathrm{~N}-\mathrm{H}) \mathrm{cm}^{-1}$, which point on the reality of received structure. There is a patent for the receiving of this compound [13].

\section{Results and discussion}

As was mentioned in introduction, such organophosphorus substances are used as effective means against the scum in the city systems. As known, the scum is a product of magnesium and calcium salts in technical waters in large degree. On this reason we undertook the determination of general rigidity and alkaline properties of technical water of Kazan town. The method of the determination of the rigidity of water was described earlier in the works $[6,14]$.

The determination of general rigidity $\left(\mathrm{R}_{\mathrm{o}}\right)$ of water (general upkeep of $\mathrm{Mg}$ and $\mathrm{Ca}$ in it) was conducted by the titration of technical water with ethylenediamine-tetraacetic acid (EDTA) with the addition of black-eriochrome (erio T) as an indicator in basic medium ( $\mathrm{pH} \sim 10)$. From general amount of EDTA was excluded the amount of EDTA, which was spent on the titration of equivalent amount of special added magnesium salt. The additional introduction of ammonia buffer blocks the ferric salts in the research technical water and makes the results more correct [14]. The result of such investigation is represented in Table 1.

The general alkali property $\left(\mathrm{A}_{\mathrm{o}}\right)$ of water was determined as the sum of hydroxyl ions and anions of weak acids [15]. This important parameter was determined through the titration of water test with componentphenolphthalein (PP) in first degree and then with methyl orange (M). Such separation in the titration allow very precisely define the amount of separate components of general alkali of water when: $\mathrm{PP}$ is between $0.2<\mathrm{M}$ and $\mathrm{pH}<9.5$. Moreover, the ions $\mathrm{HO}^{-}$and $\mathrm{HCO}_{3}{ }^{-}$cannot exist together because the reaction (3) take place mixture.

$$
\mathrm{HO}^{-}+\mathrm{HCO}_{3}^{-} \rightarrow \mathrm{CO}_{3}^{2-}+\mathrm{H}_{2} \mathrm{O}
$$

However, not only rigidity and alkali properties characterize the ability of extract means (let's give it a title anti scum) of metals in water. These is an important parameter "effectivity, Z (\%)", which can be calculated on equation (4) [16].

$$
Z=\frac{\left[C a_{\text {last }}\right]}{\left[C a_{\text {start }}\right]} \cdot 100
$$

The data of analysis of technical water $\left(\mathrm{mgr}^{-1} \mathrm{l}^{-1}\right)$ in the drainage of Kazan

\begin{tabular}{cccccc}
\hline \multirow{2}{*}{ N of test } & \multicolumn{6}{c}{ Chemical composition of technical water } \\
\cline { 2 - 6 } & $\mathbf{R}_{\mathbf{0}}$ & $\mathbf{C a}$ & $\mathbf{M g}$ & $\mathbf{p H}$ & $\mathbf{A}_{\mathbf{0}}$ \\
\hline 1 & 6.26 & 4.16 & 2.10 & 7.32 & 1.8 \\
2 & 8.42 & 4.88 & 3.54 & 8.46 & 2.1 \\
3 & 7.51 & 4.36 & 3.15 & 7.28 & 1.6 \\
4 & 6.48 & 3.76 & 2.92 & 7.93 & 1.2 \\
\hline
\end{tabular}


The components of general alkali properties of technical water

\begin{tabular}{ccccc}
\hline \multirow{2}{*}{$\begin{array}{c}\text { Relation between } \\
\mathbf{P P} \text { and } \mathbf{M}\end{array}$} & $\begin{array}{c}\text { The contain } \\
\text { of anions in water }\end{array}$ & \multicolumn{3}{c}{ The components of general alkali } \\
\cline { 3 - 5 } & $\mathrm{HCO}_{3}{ }^{-}$ & $\mathbf{C O}_{3}{ }^{2-}$ & $\mathbf{H O}^{-}$ \\
\hline $\mathrm{PP}=0$ & $\mathrm{HCO}$ & 0 & 0 \\
$2 \mathrm{PP}<\mathrm{M}$ & $\mathrm{HCO}_{3}^{-}$and $\mathrm{CO}_{3}{ }^{2-}$ & $\mathrm{M}-2 \mathrm{PP}$ & $2 \mathrm{PP}$ & 0 \\
$2 \mathrm{PP}=\mathrm{M}$ & $\mathrm{CO}_{3}{ }^{-2}$ & 0 & $2 \mathrm{PP}$ & 0 \\
$2 \mathrm{PP}>\mathrm{M}$ & $\mathrm{CO}_{3}{ }^{2-}$ and $\mathrm{HO}^{-}$ & 0 & $2(\mathrm{M}-\mathrm{PP})$ & $2 \mathrm{PP}-\mathrm{M}$ \\
$\mathrm{PP}=\mathrm{M}$ & $\mathrm{HO}^{-}$ & 0 & 0 & $\mathrm{M}$ \\
\hline
\end{tabular}

In this equation $\mathrm{Ca}_{\text {last }}$ is the contain of calcium $\left(\mathrm{mgr} \cdot \mathrm{l}^{-1}\right)$ in water after the experiment, $\mathrm{Ca}_{\text {start }}$ is the contain of calcium $\left(\mathrm{mgr} \cdot \mathrm{l}^{-1}\right)$ before the experiment.

Taking into account the all mentioned above, the research of the properties, applicability and effectivity of already synthesized EDDDP was followed on such way at the same conditions, which are pointed in Table 1(concentration of $\mathrm{Ca}, \mathrm{Mg}$, general rigidity and alkali properties):

- the synthesized anti scum was added in the analyzing waters in the amounts $2-10 \mathrm{mgr} \cdot \mathrm{l}^{-1}$ as it is recommended in literature [1719], because the amount of this agent must be proportional to the formed scum in water,

Table 3

The results of analysis $\left(\mathrm{mgr}^{-1} \mathrm{l}^{-1}\right.$ of the effectivity of EDDDP in testing water

\begin{tabular}{cccc}
\hline $\begin{array}{c}\text { No } \\
\text { of test }\end{array}$ & $\begin{array}{c}\text { Concentration } \\
\left(\mathbf{m g r}^{-\mathbf{l}} \mathbf{)}\right.\end{array}$ & Reagent & $\mathbf{Z}^{*}$ \\
\hline \multirow{2}{*}{1} & 3 & EDDDP & 97 \\
& 3 & NTPZn & 73 \\
\hline \multirow{2}{*}{2} & 5 & EDDDP & 91 \\
& 5 & NTPZn & 56 \\
\hline \multirow{2}{*}{3} & 3 & EDDDP & 99 \\
& 5 & NTPZn & 59 \\
\hline \multirow{2}{*}{4} & 3 & EDDDP & 92 \\
& 3 & NTPZn & 65 \\
\hline
\end{tabular}

*Z-Effectivity was determined as the relation of calcium and magnesium ions in water before and after experiments (eq. 4).
- four tests were heated at $363 \mathrm{~K}$ during of 3 hours and after this actions were exposed to analysis; for comparison NTPZn was used.

The results of these experiments are in Table 3.

As can be seen from the data of Table 3, the synthesized EDDDP is more effective in different concentrations then often used in a city thermal supply nitriletriphosphonate of zinc (3-rd class of the danger) for the cleaning of drainage water.

The theoretical calculation of the estimation of ecological danger for the environment was made for the suggested ethylene-diamido-diisopropyliden-O,O'dinatriumdiphosphonate (EDDDP) and have been found that this anti scum corresponds to 4-th class of the danger for the natural water reservoirs (Table 4).

The indicator $\mathrm{K}_{\mathrm{i}}$ of the degree of the scrap danger can be calculated on Eq. (5),

$$
\mathrm{K}_{\mathrm{i}}=\mathrm{C}_{\mathrm{i}} / \mathrm{W}_{\mathrm{i}}
$$

where $\mathrm{C}_{\mathrm{i}}-$ a concentration of $\mathrm{i}$-th component in the danger scrap, $\mathrm{W}_{\mathrm{i}}-\mathrm{a}$ coefficient of the degree of danger of $i$-th component, i.e. a conditional indicator, equal to the amount of the scrap component, lower of the magnitude of which it cannot in no way do a negative interaction on the environment.

The indicator $\mathrm{K}$ of the degree of the scrap danger can be calculated as a sum of Ki of the separate components of the scrap (eq. 6),

$$
\mathrm{K}=\mathrm{K}_{1}+\mathrm{K}_{2}+\ldots+\mathrm{K}_{\mathrm{i}}
$$

The results of the calculation of the danger class on the componentsof thescrap

\begin{tabular}{lcccc}
\hline \multicolumn{1}{c}{ Component } & Compound, $\%$ & $\mathbf{C}_{\mathbf{i}}(\mathbf{m g r} / \mathbf{k g r})$ & $\mathbf{W}_{\mathbf{i}}$ (mgr/kgr) & $\mathbf{K}_{\mathbf{i}}$ \\
\hline Phosphoric acid & 3.87 & 38700 & 16785.463 & 2.201 \\
EDDDP and his metabolite (in the sum) & 0.03 & 300 & 132.591 & 0.858 \\
Water /p.13 from“Criteria"/ & 96.10 & 961000 & 1000000.00 & 0.961 \\
& & & (standard) & \\
\hline
\end{tabular}


in which $\mathrm{K}_{\mathrm{i}}$ - indicators of the degree of the danger of the number (i) of the amount of the scrap. The indicator $\mathrm{K}$ for EDDDP of degree of scrap consists 4.02, on this reason this anti scum is the 4-th degree of the danger [20].

The installation of the class of danger has been done accordingly with "Criteria of reference of waste to classes of danger to a surrounding environment", which have been confirmed by the ministry of natural resources of Russian Federation from 2001 year [20].

The results of toxicological control of EDDDP are the next:

- form of the test-object: solution of EDDDP $\left(\mathrm{gr} \cdot \mathrm{dm}^{3}\right)$;

- title of the test-object: Paramecium caudatum Evidence No 01.19.229/2000;

- nature of experiment (sharp, chronical): Paramecium caudatum is sharp: Daphnia magna $\mathrm{PhR}$ 1.39.200100282 - 14.1:1:2:3:4.5-99 is sharp;

- toxicological index: for solution of EDDDP is $\mathrm{LD}_{(50)}=0$ (nontoxic),

for Daphnia magna $\mathrm{PhR}$ is $\mathrm{LD}_{(50)}=2.0$ (toxic).

\section{Conclusion}

The compound ethylene-diamido-diisopropylen$\mathrm{O}, \mathrm{O}^{\prime}$-dinatrium-diphosphonate (EDDDP) was synthetized with good yield in the first time for the aim of the rise of quality of technical drainage water. The synthesis was conducted through the condensation between 1-methylacrylic acid and 1,2-ethylenediamine and the Pudovik-reaction of the received substance and dinatriumphosphosphoric acid.

The analysis of technical drainage water was conducted and was received the data of rigidity, general alkali and toxicalproperties, effectivity of water in the absence and presence of EDDDP. Such substance has a fourth class of the danger.

The toxicological control in the accordance with "Criteria of reference of waste to classes of danger to a surrounding environment" of russianministry of natural resources from 2000 year gave the conclusion that EDDDP is nontoxic in the compassion with bacterium Daphnia magna, which was taken as the standard.

\section{Лuтература}

1. Ведрученко В.Р., Крайнов В.В., Кокшаров М.В. Промышленная энергетика. 2002. № 3. С. 24-28.

2. Контроль вредных выбросов ТЭС в атмосферу. Росляков П.В., Ионкин И.Л., Закиров И.А. и др.
/ Под ред. П.В. Рослякова. М.: Изд-во МЭИ. 2004. $25 \mathrm{c}$.

3. Ведрученко В.Р., Крайнов В.В., Кокшаров М.В. Промышленная энергетика. 2001. № 5. С. 55-60.

4. Беликов С.Е., Котлер В.Р. Промышленная энергетика. 2001. № 3. С. 53-55.

5. Ведрученко В.Р., Крайнов В.В., Кокшаров М.В., Кириенков A.B. Промышленная энергетика. 2000. № 1. C. $37-43$.

6. Овчинников В.В., Кулаков А.А. Изв. Вузов. Химия и хим.технология. 2018. Т. 61. Вып. 6. С. 109-112. DOI: $10.6060 /$ tcct.20186106.5691.

7. Потапов С.А., Дрикер Б.Н., Цирульникова Н.В. Энергосбережение и водоподготовка. 2004. №3. С. 57-60.

8. Семенова И.В., Хорошилов А.В. Энергосбережение и водоподготовка. 2000. №4. С. 85-88.

9. Чаусов Ф.Ф., Раевская Г.А. и др. Новости теплоснабжения. 2003. № 8. С. 39-43.

10. Дикарев М.А. Техника и технологии. М.: 2000. 53 с.

11. Чаусов Ф.Ф., Раевская Г.А. Комплексонный воднохимический режим теплоэнергетических систем низких параметров (Практическое руководство). М.-Ижевск: НИЦ-Регулярная и хаотическая динамика. 2003. $280 \mathrm{c}$.

12. Коновалова И.В., Бурнаева Л.А. Реакция Пудовика. Казань: Изд-во Казанского ун-та. 1991. 147 с.

13. Лаптева Л.И., Овчинников В.В. Способ получения этилиден-диамидо-диизо-пропилиден-О, $\mathrm{O}^{\prime}-$ динатрий-дифосфоната. Патент РФ №2600549. 2016. Б.И. 2016. № 29.

14. Water drinking. Methods of definition of rigidity. M.: Standardinform. 2013. 14 p.

15. Потапова Н.В. Технология умягчения воды с утилизацией сточных вод на РТС МГП «Мостеплоэнерго». Тез.докл. Международной научно-практ. Конф. «Экология энергетики 2000». М.: Изд-во МЭИ. 2000. С. 12-14.

16. Росляков П.В., Закиров И.А., Ионкин И.Л., Егорова Л.Е. Теплоэнергетика. 2005. Вып 4. С. 44-50.

17. Балабан-Ирменин Ю.В., Рудакова Г.Я., Ларченко B.E., Рубашов A.M. Энергосбережение и водоподготовка. 2005. Вып. 3. С. 5-8.

18. Росляков П.В., Егорова Л.Е., Ионкин И.Л. Технологические мероприятия по снижению вредных выбросов ТЭС в атмосферу / Под ред. П.В. Рослякова. М.: Изд-во МЭИ. 2001. 24 с.

19. Методические рекомендации по расчету количества и качества принимаемых сточных вод и загрязняющих веществ в системы канализации населенных пунктов. МДК 3-01. 2001. М.: ГосстройРоссии. 2002. $26 \mathrm{c.}$

20. Критерии отнесения отходов к классам опасности для окружающей природной среды. Министерство природных ресурсов РФ. М.: 2001 (приказ № 511). 